\title{
Exploring the Connections between Land Use and Transportation: A Case Study of Shaheb Bazar to Rail Gate Road, Rajshahi City
}

\author{
Dulal Sarker ${ }^{1}$, Abdur Rouf Khan ${ }^{1}$ and Muhaiminul Islam ${ }^{1 *}$ \\ ${ }^{1}$ Rajshahi University of Engineering \& Technology, Department of Urban \& Regional Planning, \\ Rajshahi, Bangladesh; Email: dulalsarker.ruet@gmail.com, abdur.rouf.khan@outlook.com, \\ muhaiminul.urp13@gmail.com
}

*Corresponding Author: Muhaiminul Islam

\begin{abstract}
Land use-transportation comprehensive planning has become an increasingly common technique in regional and sub-regional planning processes. Since land use management strategies act as an effective tool to achieve transportation planning objectives, it is important to identify the relationship between land use pattern and travel behaviour. This study examined the relationship between transportation and land use in Rajshahi city. Rajshahi is a major urban, commercial and educational centre of Bangladesh. In Rajshahi, Shaheb bazaar zero points to New Market road is one of the most important roads. After construction of this road in 2013 intense development has taken place beside it. To identify this primary relationship data has been collected from different types of field survey. Then the impact of land use and transportation has been determined by comparing with the previous database. The findings of the study show that there exist a reciprocal relationship between land use and transportation system and the impacts on both. The study also notes that the impact of transportation on land use is more than the impact of land use on transportation. The study will help to control the haphazard growth and traffic congestion of the concerned area in the future.
\end{abstract}

Keywords: Land-use, land-use, transport interaction, V/C ratio

\section{Introduction}

There has been flourishing interest in the land use-transportation affinity in the past decade, spurred by the possibility that design policies associated with the built environment can be used to control, manage, and shape individual traveller behaviour and aggregate travel demand [1]. Rajshahi is the fourth metropolitan city of Bangladesh. It displays a highly-mixed pattern of land use extending east-west and north-south (the recent trend) linearly along the main roads [2]. Mode influences travel behaviour and available modes influence development patterns. This relationship between land use and transport safety and security needs to be better investigated [3]. A major term having a huge impact on the transportation system is land use. Different types of land use in Rajshahi city 
mostly determine the shape of the transportation system. The role of transportation professionals is evolving and more frequently requires them to understand how transportation investments can be consistent with the principles and practices of land use planning and development [4].

At a minimum, the coordination of land use and transportation requires that those concerned with the well-being of a community (or region, state or nation) assess an evaluate how land use decisions affect the transportation system and can increase viable options for people to access opportunities, goods, services and other resources. Rajshahi city is facing rapid changes in land uses every year in every area. The previous land uses used to generate certain types of traffic [2]. The changed land uses have significant changes in the pattern of generation of traffic and most of the cases, the new impacts are harmful. This study aims at finding out the impacts of different types of land uses on the transportation system of Rajshahi city and vice versa. Shaheb bazar to the new market road is a very important arterial road of Rajshahi city which have been facing significant changes in its adjacent land uses [5]. In a developing country like Bangladesh, Efficiency of the road network can be achieved through proper transportation planning, and impact assessment of particular land uses indicates the possibilities of transportation planning [6].

\section{Literature Review}

Land-use is composed of two distinct attributes: the nature of land use, which relates to which activities are taking place where, and the level of spatial accumulation, which indicates their intensity and concentration [7]. On the other hand, Transport System considers as set of infrastructures and modes that are supporting urban movements of passenger and freight. Both of these are significantly correlated with one another to some extent [8]. Complexity exists between the relationship between land use and travel behavior because there are multiple attributes of land use intertwining with various aspects of travel behaviour [9]. Some important physical infrastructure, e.g., sewerage and highways, can influence land development significantly and on the other hand patterns of land use can affect the utilization and performance of infrastructure [10]. The association between land-use development patterns and the travel behaviour of individuals is reflected in the different trip generation rates and (sometimes) mode shares attributed to different land-use development patterns, which is assumed by the transportation engineers and planners several decades back [11]. However, there is no rigorous attempt to explain the relationship explicitly or mechanism that generates the association between land use and travel demand in such transportation planning practice [12]. There has been an elucidating and lively body of literature altercating the ecological versus the associative nature of the relationship between transportation development and travel behaviour [13]. On the one side of the debate, proponents of the new urbanism and smart growth concepts claim that the association between the land use and travel 
behaviour represents a causal effect, and is of a sufficient enough magnitude to lead to tangible reductions in motorized vehicle use.

In the 1950s first efforts were made in the USA to study the interrelationship between transport and the spatial development of cities systematically [14]. Hansen demonstrated for Washington, DC that locations with good accessibility had a higher chance of being developed, and at a higher density, than remote locations. The recognition that trip and location decisions co-determine each other and that therefore transport and land use planning needed to be coordinated, quickly spread among American planners, and the 'land-use transport feedback cycle' became a commonplace in the American planning literature [15]. Zhang [16] analyzed the influence of land use on travel mode choice using survey data from Metropolitan Boston and Hong Kong. In Boston, the focus of the inquiry was on whether land use would still matter for mode choice (and if so, to what extent) when mode attributes and traveller socioeconomic characteristics were taken into account. In Hong Kong, where the role of land use in mode choice is obvious due to the densely built environment, the focus was on whether land use completely explained the transit-dominated travel pattern. Kitamura et al. [17] also observed a positive correlation between residential density and the share of no motorized trips. Handy [18] reported that a pedestrian-friendly environment encouraged walking for shopping travel; but people in the modern neighbourhoods walked to stores as well, if the stores were located in easy walking distance. In this study, Handy offered an important observation: Land use made a difference in determining whether residents perceived walking as an option available to them. In other words, land use influences the choice set formation of travel modes feasible to the traveller. Choice set formation is the first and critical stage of an individual's mode choice decision [19].

Although transportation-land use interactions are widely acknowledged as being important, there are few practical methods for predicting these interactions for a particular region and infrastructure investment. So this study identified the relationship between land use and transportation infrastructure.

\section{Study Area Profile}

Shaheb Bazar to Rail Gate Road in Rajshahi city is this research's study area. Shaheb Bazar to Rail Gate Road is one of the busiest roads in Rajshahi city. A large number of developments have been seen along this roadside land in recent years. Lots of commercials, mixed-used buildings are seen besides the roads. This road reconstructed in 2014. It was developed by Rajshahi Development authority (RDA). The road length has expanded to $1200 \mathrm{~m} \&$ width about $18.28 \mathrm{~m}$ by RDA (see Fig. 1). 


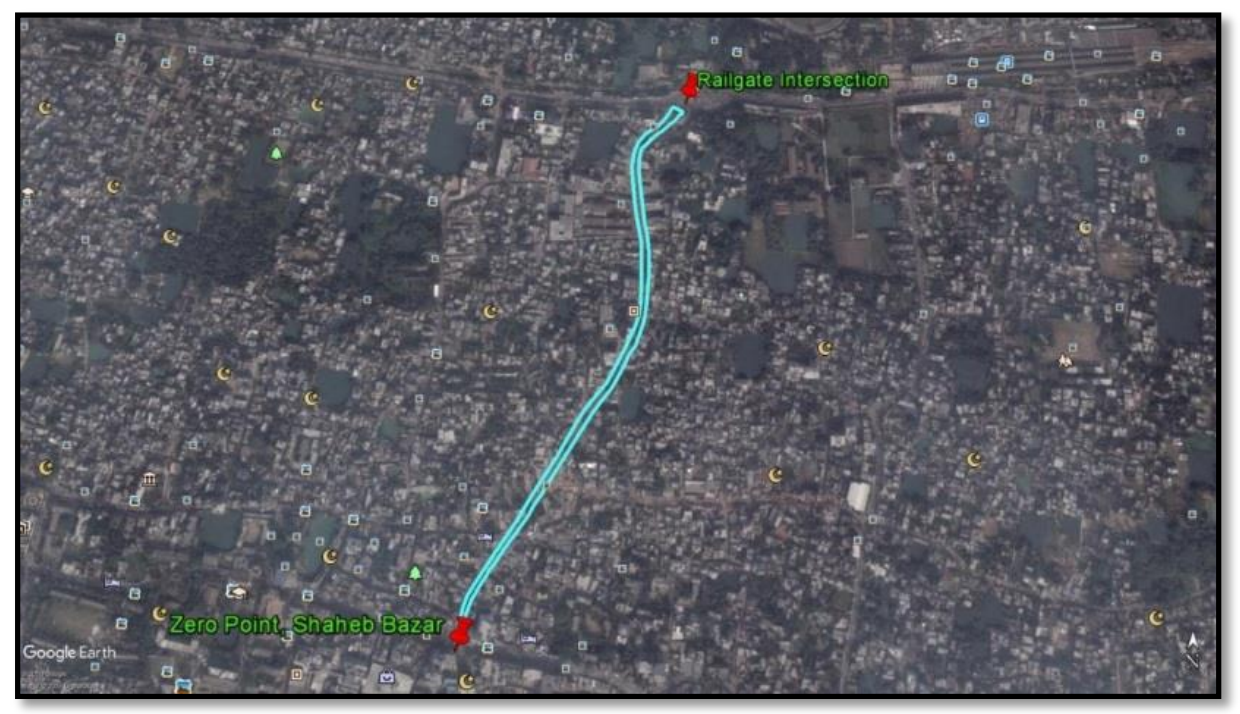

Fig. 1 Shaheb bazar to rail gate road. Source: authors

\section{Data and Methods}

The objective of the study is to found out the reciprocal relationship between land use and transportation system and the impacts on both. For the study, data has been collected two different sources which are the primary and secondary source. Primary data has been collected from different types of field survey, i.e. land use survey, volume survey and questionnaire survey. And secondary data has been collected from different journal, report and other related publications. Then, different types of statistical analysis have done with the help of statistical software (SPSS).

\section{Volume capacity ratio (V/C ratio) method}

This method is used to calculate the Level of Service (LOS). The mathematical formula is shown below by equation (1) [4].

$$
\operatorname{LOS}=\frac{V}{C}, \quad[-]
$$

where: $V$ is the total number of vehicles passing a point in one hour [pcs]; $C$ is the capacity [pcs].

$$
C=\frac{\text { Design Capacity } \times \text { Effective Width }}{12}, \quad[-]
$$

\section{Results - Impact of Land Use Change on Transportation}

\section{Comparison of Peak Hourly Volume}

The comparison of Peak Hourly Volume has made between two years which are 2004 and 2016. From Figure 2, it has found that the Peak Hourly Volume has been changed from 2004 to 2016. This is because total land use change throughout the Rail Gate Road produces a large amount of traffic. Peak hour volume has been increased with the Growth of buildings and Change in use most of the land use of the buildings from residential to commercial and mixed use. 


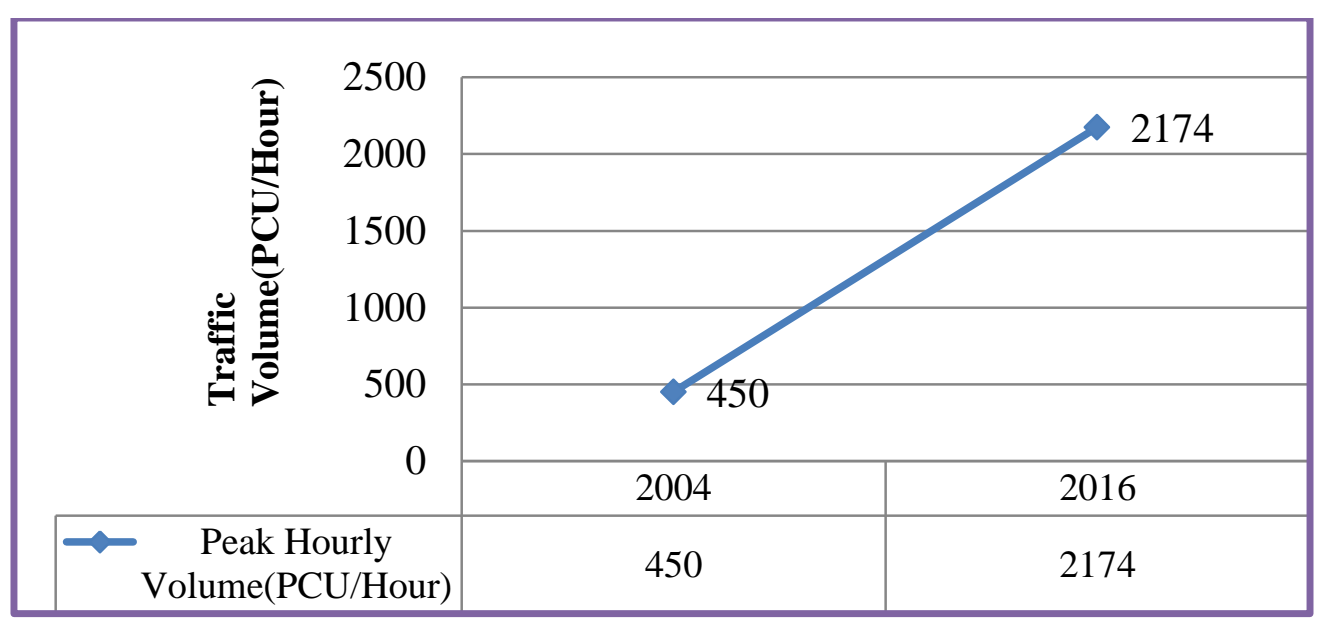

Fig. 2 Comparison of peak hourly volume. Source: [20]

\section{Comparison of Level of Service (for Peak Hourly Traffic Flow)}

The comparison of Level of Service has been made between two years which are 2004 and 2016. To assess the impact of land use change two stages of Level of Services have been used for the analysis. From Table 1, it has found that the Level of Service has been changed from 2004 to 2016. This is because total land use change throughout the Rail Gate Road produces a large amount of traffic.

Table 1 LOS of the rail gate road. Source: authors

\begin{tabular}{cccccccc}
\hline Time & Direction & Volume & $\begin{array}{c}\text { Effective Road } \\
\text { Width }\end{array}$ & Design & Capacity & $\begin{array}{c}\text { V/C } \\
\text { ratio }\end{array}$ & LOS \\
\hline 2016 & $\begin{array}{c}\text { Shaheb Bazar Road to } \\
\text { Rail gate }\end{array}$ & $\mathbf{2 0 0 0}$ & 24 & 1200 & 2400 & $\mathbf{0 . 8 0}$ & $\mathbf{C}$ \\
\hline 2004 & $\begin{array}{c}\text { Shaheb Bazar Road to } \\
\text { Rail gate }\end{array}$ & 450 & 14 & 1200 & 1400 & 0.34 & $\mathbf{A}$ \\
\hline
\end{tabular}

The level of service of Rail Gate Road was determined as "A" and "C" in two study period 2004 and 2016 respectively though the effective carriageway width has been increased from 14 feet to 24 feet over the period. However, the impact of land use change has increased the volume and also the Level of Service of the selected study area.

\section{Results - Impact of Transportation on Land Use Change}

\section{Comparison of the Effective Road Width}

By geometric feature survey, the carriageway width has been measured in both directions of the selected road. From Table 2, it is found that the effective road width has been changed from 2004 to 2016. The capacity of the road has also been changed from 1400 to 2400 from 2004 to 2016 . 
Table 2 Effective road width of rail gate road. Source: authors

\begin{tabular}{cccl}
\hline Time & Effective Road Width (feet) & Design PCU & Total Capacity (PCU/Hr) \\
\hline 2016 & 24 & 1200 & 2400 \\
\hline 2004 & 14 & 1200 & 1400 \\
\hline
\end{tabular}

\section{Changes of Land Use over the Period 2004-2016}

As a result of increased the effective roadway width and capacity of the road, the land use has been changed to a great extent. From Figure 3, it is found that land use has been changed from 2004 to 2016. Of them, mainly commercial and Mixed-use buildings have been increased a great number, but residential buildings have been decreased from 2004 to 2016. These commercial and Mixed land uses to attract and generate more traffic than residential land use. These land use changed occurred with the increased capacity of the road. In 2004, about 55\% building along Shaheb bazar to Rail gate road was used for commercial purpose. In 2016, commercial land use was increased from $55 \%$ to $66 \%$. Mixed land use also showed an increasing trend along this road. Only residential land use has decreased as a result of increased land price and rent. In 2004 there were 30\% of residential buildings, which have become only 9\% in 2016.

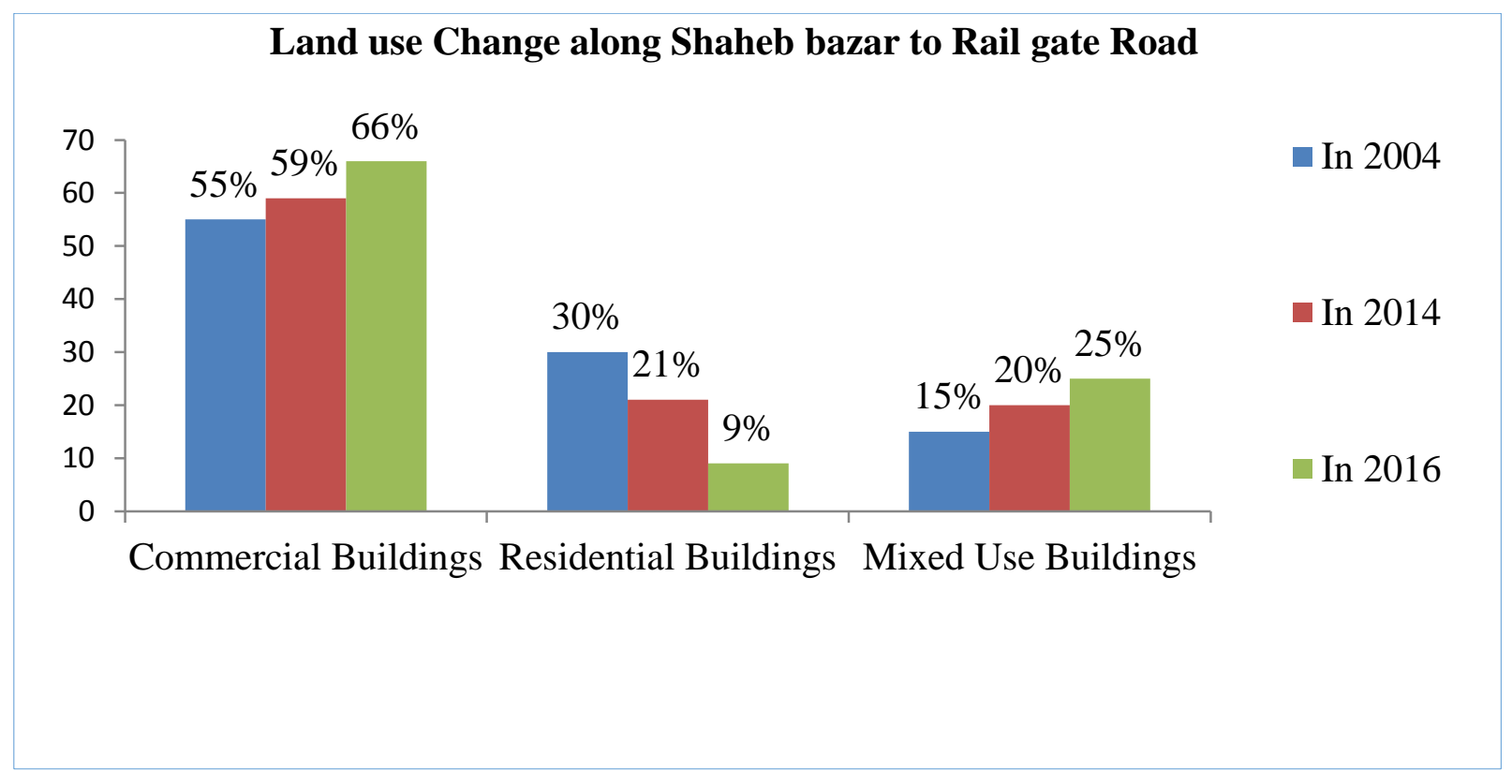

Fig. 3 Change of land use over the period 2004-2016. Source: [20]

\section{Changes in Building Growth Rate Over the Period 2004-2016}

The building growth rate has been increased with the increased of roadway capacity and increased the effective width of the road. The growth rate of building rapidly changes from $2.68 \%$ to $5.6 \%$ over the period from 2014 to 2016 after the Shaheb bazar to Rail gate road has been enlarged (see Fig. 4). 


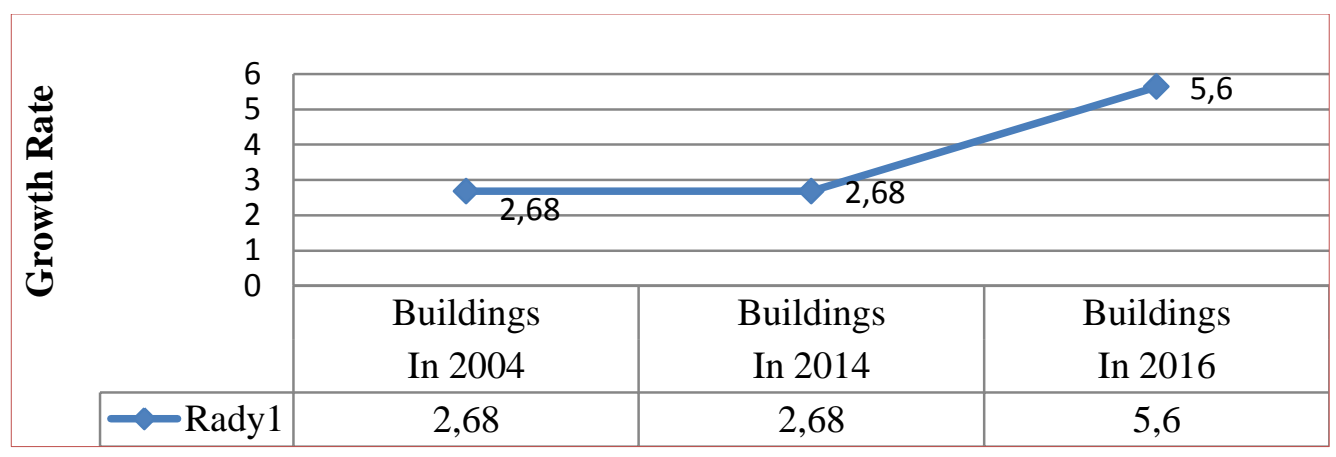

Fig. 4 Building growth rate. Source: [20]

\section{Changes of Land price over the Period 2004-2016}

After the re-construction of Shaheb bazar to Rail gate road, the accessibility to the road has been improved. With the changed of the land use over the period and increased the growth rate of the buildings, the price of the land has been increased dramatically. From Table 3, it is found that the average price of land per Katha has been changed 2.8 Million to 7.8 Million BDT over the period 2004 to 2016.

Table 3 Changes in land price. Source: authors

\begin{tabular}{cccc}
\hline \multicolumn{2}{c}{ Land price (per Katha) in 2004 } & \multicolumn{2}{c}{ Land price (per Katha) in 2016 } \\
\hline Minimum & 2.2 Million & Minimum & 5.5 Million \\
\hline Maximum & 3.5 Million & Maximum & 10.0 Million \\
\hline Average & 2.8 Million & Average & 7.8 Million \\
\hline
\end{tabular}

\section{Changes of Building Storied over the Period 2014-2016}

From the Figure 5, it is found that after the enlargement of the Shaheb bazar to Rail gate road, the percentage of vertical expansion of the buildings has been increased from 2014 to 2016. Percentage of multi stories buildings has been increased by $25 \%$ to $47.5 \%$ over the period. This is because of the increased the price of land of buildings the vertical expansion of the buildings along the roads has been increased.

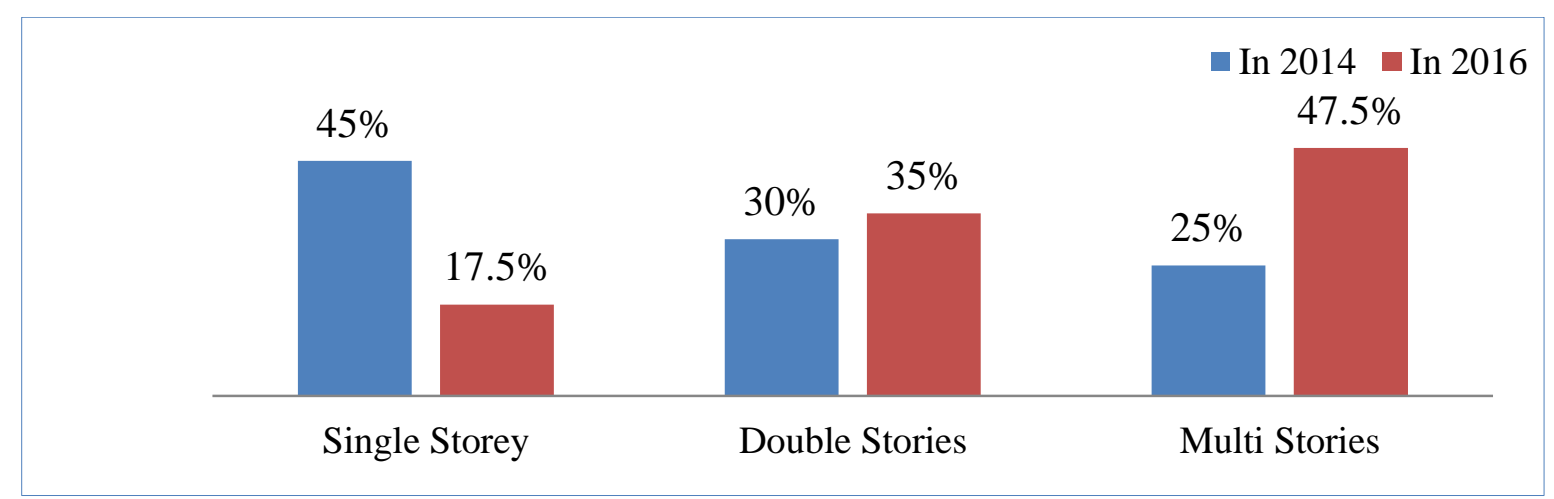

Fig. 5 Changes of building storied over the period 2014-2016. Source: [20] 


\section{Discussion}

\subsection{Temporal Changes of Physical Condition of Road}

According to a field survey in the year 2004, the effective carriageway was 14 feet, and the lane of the road was two. In the year 2016, as a result of Shaheb bazar to Rail gate road expansion, the effective carriageway becomes 48 feet, and the lane of the road has become four. Main changes of geometric features of this road are given Table 4.

Table 4 Physical condition of road. Source: authors

\begin{tabular}{ccccccc}
\hline Time & Road & Shoulder & Effective carriage way & Median island & Footpath & Lane \\
\hline 2016 & $\begin{array}{c}\text { Rail gate to New } \\
\text { market }\end{array}$ & 5 feet & 48 feet & 6 feet & 8 feet & 4 \\
\hline 2004 & $\begin{array}{c}\text { Rail gate to New } \\
\text { market }\end{array}$ & 5 feet & 14 feet & & 5 feet & 2 \\
\hline
\end{tabular}

\subsection{Traffic Composition in $2004 \& 2016$}

In 2004, the hourly dominated vehicle was paddle Rickshaw which was $81 \%$ of the total vehicles' composition. The traffic composition of auto rickshaw was $3 \%$, the bicycle was $10 \%$, and the bus was only $2 \%$ (see Fig. 6).

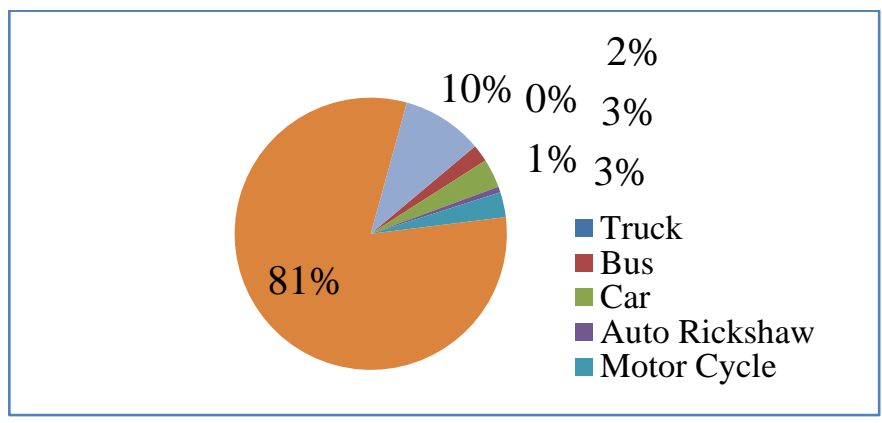

Fig. 6 Hourly traffic composition in 2004. Source: [20]

Traffic composition in 2016 has been changed significantly. The easy bike has become the most dominated vehicle among the vehicles. Traffic composition of auto rickshaw, paddle rickshaw, bicycle, motorcycle, the van is $20 \%, 14 \%, 5 \%, 4 \%$ and $3 \%$ respectively (see Fig. 7 ).

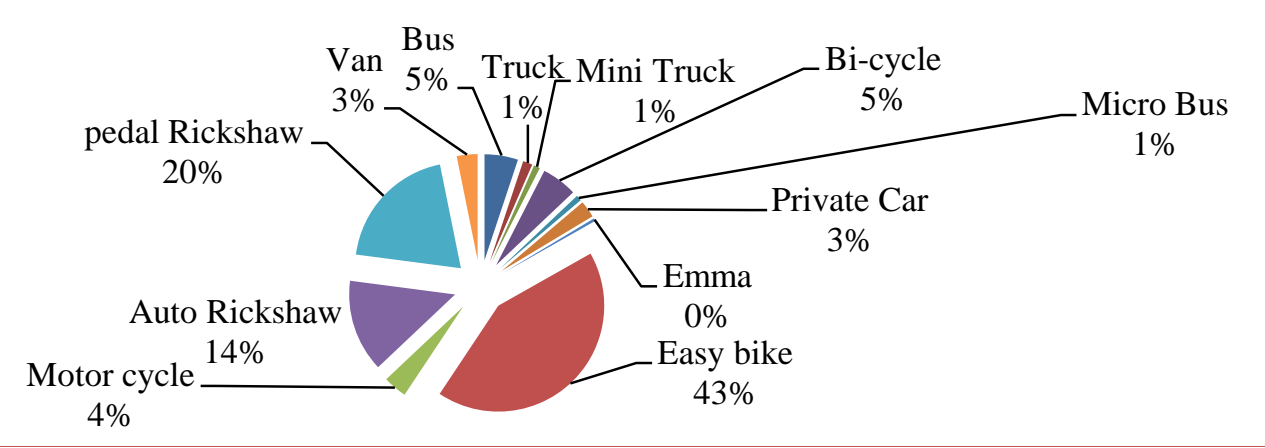

Fig. 7 Hourly traffic composition of shaheb bazar - Rail gate rouad in 2016. . Source: [20] 


\subsection{Changes of Land Rent along Shaheb Bazar to Rail Gate Road}

In 2004, about 57\% lands rent (per sq/ft) along Shaheb bazar to Rail gate road was 9-10 Taka. Approximately $27.5 \%$ of land's rent was 5-8 taka and 15\% Land's rent was more than 10 taka (see Fig. 8). In 2016, most of the land's rent (per sq/ft) becomes more than 30 takas. There are only $12.5 \%$ of land's rents within the range of 20 to 25 taka (see Fig. 8). This rapid increasing land rent also indicates the development and demand of space around this Shaheb bazar to rail gate road area.

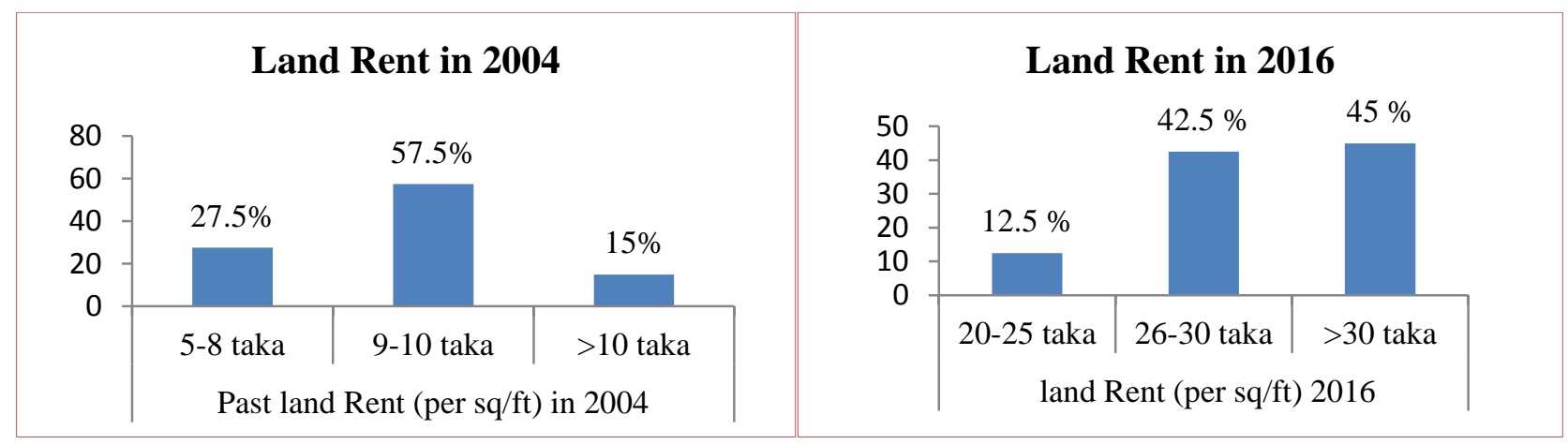

Fig. 8 Changes of land rent over the period 2004-2016. Source: [20]

\subsection{Forecasting Traffic Volume for 2018}

Natural growth in traffic is derived from the annual growth rate. For forecasting traffic volume for the year 2018, the traffic volume data of 2016 is used. Only peak hour volume data have taken into account for forecasting future traffic volume. From the data, it is found that the yearly growth rate of traffic is $6.60 \%$ (see Table 5). By using the general annual growth rate, traffic volume for 2018 is forecasted. The predicted traffic volume in 2018 is $2461 \mathrm{PCU} / \mathrm{hr}$ (see Table 6).

Table 5 Growth rate of traffic. Source: authors

\begin{tabular}{ccccc}
\hline $\begin{array}{c}\text { Peak Hourly } \\
\text { Volume }\end{array}$ & $\begin{array}{c}\text { Peak Hourly } \\
\text { Volume }\end{array}$ & $\begin{array}{c}\text { Increase in 12 } \\
\text { years }\end{array}$ & $\begin{array}{c}\text { Annual } \\
\text { Growth }\end{array}$ & $\begin{array}{c}\text { Growth } \\
\text { Rate }\end{array}$ \\
\hline 450 & 2174 & 1724 & 144 & $6.60 \%$ \\
\hline
\end{tabular}

Table 6 Predicted Traffic Volume in 2018. Source: authors

\begin{tabular}{ccccc}
\hline Types of Vehicle & Total & $\begin{array}{c}\text { Annual growth } \\
\text { the rate for two years }\end{array}$ & $\begin{array}{c}\text { Forecasted } \\
\text { Increased Volume }\end{array}$ & $\begin{array}{c}\text { Forecasted Volume } \\
\text { for 2018 }\end{array}$ \\
\hline Total & 2174 & 0.132 & 287.0 & $\mathbf{2 4 6 1 . 0}$ \\
\hline
\end{tabular}




\section{Conclusion}

There is a strong relationship between land use components and transportation. Transportation has greater impacts on land use for this study area. After the expansion of Shaheb bazar to Rail gate road, the land price and land rent have increased dramatically along the roadside which is $36 \%$ and $30 \%$ respectively. Commercial and mixed land use change is in the dominating position, and Residential land use change is in a negative trend. So, more and more adjacent plots are being commercialised. Because of the excellent accessibility and existence of most of the commerce and business centre, people prefer more to come to this place from different parts of the city. The average carriageway width of the road is 48 feet in both directions combined which is entirely satisfactory but the peak hour traffic volume $2174 \mathrm{PCU}$ is quite high. The vehicle capacity ratio (v/c) is increasing over time which indicates deterioration of the road condition according to the standards of the level of services.

\section{Reference}

[1] Waddell, P. et al. (2007). Incorporating land use in metropolitan transportation planning. Transportation Research Part A: Policy and Practice. 41(5), 382-410.

[2] R.D.A. (2004). Rajshahi Metropolitan Development Plan. 2004-2024 Volume-II Detailed Area Plan. 2004, Ministry of Housing and Public Works Government of the People's Republic of Bangladesh.

[3] Dargay, J.M. \& M. Hanly. (2003). The impact of land use patterns on travel behaviour. in European Transport Conference, Strasbourg, France.

[4] Kockelman, M.K. (1997). Travel behaviour as function of accessibility, land use mixing, and land use balance: evidence from San Francisco Bay Area. Transportation research record. 1997. 1607(1), 116-125.

[5] Rahman, M.M. (2010). Factors of economic transformation in sub-urban areas of Rajshahi City, Bangladesh. Journal of Life and Earth Science. 5, 47-55.

[6] Rahman, R., Shakil S.H. \& Quader, K.B.A. (2011). Impact on different type of land uses on transportation system of Dhaka city: A case study of Mirpur road and its adjacent land uses. Bangladesh University of Engineering and Technology.

[7] Beilin, R. et al. (2014). Analysing how drivers of agricultural land abandonment affect biodiversity and cultural landscapes using case studies from Scandinavia, Iberia and Oceania. Land use policy. $36,60-72$. 
[8] Helming, K. et al. (2008). Ex ante impact assessment of land use changes in European regions-The SENSOR approach, in Sustainability Impact Assessment of Land Use Changes. Springer. 77-105.

[9] Litman, T. \& Steele, R. (2012). Land use impacts on transport: How land use factors affect travel behavior. Victoria Transport Policy Institute Victoria, BC., Canada.

[10] Cavalli-Sforza, V. \& Ortolano, L. (1984). Delphi forecasts of land use: Transportation interactions. Journal of Transportation Engineering. 110(3), 324-339.

[11] Pérez-Soba, M. et al. (2008). Land use functions - a multifunctionality approach to assess the impact of land use changes on land use sustainability. Sustainability impact assessment of land use changes. Springer. 375-404.

[12] Huang, H. (1996). The land-use impacts of urban rail transit systems. Journal of Planning Literature, 11(1), 17-30.

[13] Vessali, K.V. (1996). Land use impacts of rapid transit: A review of the empirical literature. Berkeley Planning Journal. 11(1).

[14] Hansen, W.G. (1959). How accessibility shapes land use. Journal of the American Institute of planners. 25(2), 73-76.

[15] Knight, R.L. \& Trygg, L.L. (1977). Evidence of land use impacts of rapid transit systems. Transportation. 6(3), 231-247.

[16] Zhang, M. (2004). The role of land use in travel mode choice: Evidence from Boston and Hong Kong. Journal of the American planning association. 70(3), 344-360.

[17] Kitamura, R., Mokhtarian, P.L. \& Laidet, L. (1997). A micro-analysis of land use and travel in five neighborhoods in the San Francisco Bay Area. Transportation. 24(2), 125-158.

[18] Handy, S.L. (1996). Understanding the link between urban form and nonwork travel behavior. Journal of planning education and research. 15(3), 183-198.

[19] Manski, C.F. (1977). The structure of random utility models. Theory and decision. 8(3), 229254.

[20] Hat Bazaar Survey 2001-2002 \& Field Survey 2016. 